\title{
Antecedents and Outcomes of Customer Satisfaction: A Comprehensive Review
}

\author{
Vadivelu Thusyanthy $^{1} \&$ Vadivelu Tharanikaran ${ }^{2}$ \\ ${ }^{1}$ Department of Economics and Management, Vavuniya Campus of the University of Jaffna, Sri Lanka \\ ${ }^{2}$ Department of Commerce, Eastern University, Sri Lanka, Vantharumoolai, Chenkalady, Sri Lanka \\ Correspondence: Vadivelu Thusyanthy, Department of Economics and Management, Vavuniya Campus of the \\ University of Jaffna, Pambaimaddu, Vavuniya, Sri Lanka. E-mail: thusi86@yahoo.com
}

Received: July 24, 2016

doi:10.5539/ijbm.v12n4p144
Accepted: February 12, 2017

Online Published: March 26, 2017

URL: https://doi.org/10.5539/ijbm.v12n4p144

\begin{abstract}
Understanding the antecedents and outcome variables of customer satisfaction is become an important issue, since there are few comprehensive studies conducted related to the various antecedent and outcome variables of customer satisfaction as a whole. Therefore, the main aims of this qualitative study are to investigate and to build two comprehensive models related to the antecedent and outcome variables of customer satisfaction with the various literature supports. Importantly, the comprehensive and complex models contributes to the existing literature and enhances the future studies, which are related in both online and offline customer satisfaction contexts.
\end{abstract}

Keyword: customer satisfaction, antecedents, outcomes, variables, comprehensive model

\section{Introduction}

Customer satisfaction construct has been considered as fundamental to marketing for over the three decades. Keith (1960) defines marketing as satisfying the needs and desires of the consumer, and this definition for marketing emphasizes the significance of customer satisfaction. Further, customer satisfaction is vital for each organization to get competitive advantage resulting in customers less sensitive to price change, less marketing expenditure, financial performance, higher profit, shareholder value, return on investment, positive word-of-mouth, consumer based retailer equity, firm based brand equity, customer loyalty, purchase intension, repeat-purchase intention and customer retention (Bearden \& Teel, 1983; Fornell, 1992; Hallowell, 1996; Fornell, Johnson, Anderson, Cha, \& Bryant 1996; Anderson, Fornell, \& Rust, 1997; Brady \& Robertson, 2001; Nilssona, Johnsonb, \& Gustafsson, 2001; Rust, Moorman, \& Dickson, 2002; Anderson, Fornell, \& Mazvancheryl, 2004; Matzler, Hinterhuber, Daxer, \& Huber 2005; Al-Hawari \& Ward, 2006; Fornell, Mithas, Morgeson, \& Krishnan 2006; Pappu \& Quester, 2006; Lin, Wu, \& Chang, 2011; Torres \& Tribo, 2011; Thusyanthy \& Senthilnathan, 2012). Nevertheless, physical evidence, employee interaction, product, place, promotion, people, process, delivery performance, supplier know-how, personal interaction, brand personality, brand experience, adaptive selling, dominance, employee satisfaction, customer orientation of service employees, organizational culture, service convenience, perceived value, personality factors, equity, customer based brand equity, customer expertise, customer's experience and service quality (e.g., Johnson \& Fornell, 1991; Andreassen, 2000; Yelkur, 2000; Nilssona et al., 2001; Naser, 2002; Sureshchandar, Rajendran, \& Anantharaman, 2002; Hennig-Thurau, 2004; Lai, 2004; Gillespie, Denison, Haaland, Smerek, \& Neale 2008; Brakus, Schmitt, \& Zarantonello, 2009; Cater \& Cater, 2009; Padma, Rajendran, \& Lokachari, 2010; Santouridis \& Trivellas, 2010; Nam, Ekinci, \& Whyatt, 2011; AmyPoh, Saludin, \& Mukaidono, 2012; Evanschitzky, Sharma, \& Prykop, 2012; Jeon \& Choi, 2012; Sarker, Aimin, \& Begum, 2012; Thusyanthy \& Senthilnathan, 2012; Kaura, 2013; Mucai, Mbaeh, \& Noor, 2013; Islam, Kassim, Ali, \& Sadiq 2014; Jani \& Han, 2014; White, 2015) have been identified as antecedents affecting customer satisfaction in previous studies. Although the preceding discussions indicate many antecedent and outcome variables are associated with customer satisfaction, there are few comprehensive studies conducted related to these various antecedent and outcome variables of customer satisfaction as a whole. This is considered as the gap and the current study attempts to fill the gap in the literature. Therefore, the main purposes of this study are to investigate and to build two comprehensive models related to the relationship variables (i.e., both antecedent and outcome variables) of customer satisfaction (see Figure 1 and Figure 2). Notably, these 
comprehensive models' creation format is consistent with the previous studies (Rukshani \& Senthilnathan, 2013; Thusyanthy, 2014; Thusyanthy \& Tharanikaran, 2015; Karunakaran \& Thusyanthy, 2016).

The rest of the study is organized as follows: the next section gives the definitions for customer satisfaction, followed by its antecedents and outcomes. The final section offers the conclusion.

\section{Customer Satisfaction}

\subsection{Definitions of Customer Satisfaction}

One of the basic and important goals of any organization is to create high level of customer satisfaction. Howard and Sheth (1969) define satisfaction as 'the buyer's cognitive state of being adequately or inadequately rewarded for the sacrifice he has undergone'. According to Rust and Oliver (1994) customer satisfaction is an extent to which a person believes that an experience creates positive feelings. Oliver (1997) also defines customer satisfaction as:

Satisfaction is the consumer's fulfillment response. It is a judgment that a product or service feature, or the product or service, itself, provided (or is providing) a pleasurable level of consumption related fulfillment, including levels of under- or over-fulfillment.

Even though many authors define customer satisfaction including, Howard and Sheth (1969), Churchill and Suprenant (1982), Tse and Wilton (1988), Anderson, Fornell, and Lehmann (1994), Getty and Thompson (1994), Halstead, Hartman, and Schmidt (1994), Rust and Oliver (1994), and Oliver (1997), this study uses Oliver (1997) definition, where this definition is cited in many customer satisfaction related past studies (e.g., Oliver, 1999; Giese \& Cote, 2000; Rossomme, 2003; Pappu \& Quester, 2006; Estiri, Hosseini, Yazdani, \& Nejad 2011).

\subsection{Antecedents Associated with Customer Satisfaction}

There can be widely reported antecedents of customer satisfaction include service quality, service convenience, perceived value, personality factors, brand personality, brand experience, employee satisfaction, adaptive selling, dominance, customer orientation of service employees, equity, customer based brand equity, customer expertise, customer's experience, marketing mix and extended marketing mix elements, delivery performance, supplier know-how, personal interaction and organizational culture (e.g., Pugh et al., 1983; Johnson \& Fornell, 1991; Oliver, 1993; Andreassen, 2000; Yelkur, 2000; Naser, 2002; Hennig-Thurau, 2004; Gountas \& Gountas, 2007; Gillespie et al., 2008; Brakus et al., 2009; Cater \& Cater, 2009; Hu, Kandampully, \& Juwaheer, 2009; Nam et al., 2011; AmyPoh et al., 2012; Evanschitzky et al., 2012; Thusyanthy \& Senthilnathan, 2012; Kaura, 2013; Mucai et al., 2013; Jani \& Han, 2014; Yuen \& Thai, 2015).

Justice theory emerges from equity theory (Adams, 1965) and social exchange theory (Blau, 1960), and other empirical evidences in the literature suggest that service quality and its dimensions such as, reliability, speed, responsiveness, value, empathy, service architecture, convenience service encounter, employee service criteria and customer focus are the antecedents of customer satisfaction (Oliver, 1993; Dabholkar, Shepherd, \& Thorpe, 2000; Heung, Wong, \& Qu, 2002; Sureshchandar et al., 2002; Ekinci, Dawes, \& Massey, 2008; Lien \& Kao, 2008; Awan, Bukhari, \& Iqbal, 2011; Tan, 2014; Yuen \& Thai, 2015). Indeed, Kaura (2013) indicates that service quality dimensions namely, employee behaviour and information technology, and the dimensions of service convenience namely, decision convenience, access convenience, transaction convenience, benefit convenience and post - benefit convenience, are as antecedents have positive impact on customer satisfaction for public sector banks in India. Subsequently, previous studies have suggested that service quality and perceived value affect on customer satisfaction (Lai, 2004; Hu et al., 2009; Adeola \& Adebiyi, 2014). However, some studies imply that this perceived value moderates the relationships between service quality and customer satisfaction (e.g., Ismail, Abdullah, \& Francis, 2009a; Ismail, Alli, \& Abdullah, 2009b; Raza, Siddiquei, \& Awan, 2012), whereas Malik (2012) argues perceived value does act as a mediating variable in the relationship between service quality and customer satisfaction.

According to Orth, Limon, and Rose (2010), and Jani and Han (2014) personality factors, especially Big Five Factors that include openness to experience, conscientiousness, extraversion, agreeableness, and neuroticism have influence on customer satisfaction, while Gountas and Gountas (2007) argue that Jungian personality factors of thinking, material, feeling, and intuitive impact on customer satisfaction. Nevertheless, Brakus et al. 2009 assert that brand personality dimensions including, ruggedness, sophistication, competence, excitement, sincerity, and brand experience and its dimensions-sensory, affective, intellectual, behavioural experiences affect consumer satisfaction. 
Analysis of past studies suggests that employee satisfaction leads to customer satisfaction (Pugh et al., 1983; Jeon \& Choi, 2012). Further, both employee satisfaction and adaptive selling positively impact customer satisfaction, while dominance is negatively related to customer satisfaction (Evanschitzky et al., 2012). Notably, Jeon and Choi (2012) argue that self efficiency and corporate orientation moderate the impact of employee satisfaction on customer satisfaction. Nevertheless, Hennig-Thurau (2004) assets that customer orientation of service employees, consisting of employees' technical skills, social skills, motivation, and decision-making power has a positive influence on customer satisfaction.

According to the equity theory roots from exchange, dissonance, and social comparison theories, an individual's satisfaction or dissatisfaction judgment is based on the comparison of input against output, and compare them with other people in the same condition (Adams, 1965; Adams \& Freedman, 1976; Huseman, Hatfield, \& Miles, 1987; Oliver \& Swan, 1989; Oliver, 1997; Andreassen, 2000). Therefore, as consistent with equity theory it is possible to argue that equity have a significant impact on customer satisfaction (Andreassen, 2000; Naser, 2002). In addition, customer based brand equity and its five dimensions namely, physical quality, staff behaviour, ideal self-congruence, brand identification and lifestyle-congruence are found to have positive impact on customer satisfaction (Nam et al., 2011). Furthermore, customer expertise and its dimensions namely, expertise and familiarity (Alba \& Hutchinson, 1987) are negatively related to customer satisfaction (Naser, 2002). In addition, customers' experience with the products and services leads to customer satisfaction (Johnson \& Fornell, 1991).

Marketing mix elements namely, product, price, place and promotion (i.e., 4Ps) and extended marketing mix elements people, process and physical evidence (i.e., extended 3Ps) are the antecedents of customer satisfaction (Yelkur, 2000; AmyPoh et al., 2012; Thusyanthy \& Senthilnathan, 2012; Mucai et al., 2013). Moreover, Cater and Cater (2009) imply that customer satisfaction to be negatively affected by price, whilst positively by delivery performance, supplier know-how and personal interaction. Further, organizational culture along with the four dimensions: involvement, consistency, adaptability, and mission relates significantly and positively to customer satisfaction (Gillespie et al., 2008).

The summarized description for the above mentioned antecedents of customer satisfaction are shown in the Table 1.

Table 1. Antecedents of customer satisfaction

\begin{tabular}{|c|c|}
\hline Antecedents of customer satisfaction & Source \\
\hline Service quality $\rightarrow$ customer satisfaction & $\begin{array}{l}\text { Oliver (1993); Dabholkar et al. (2000); Heung et al. (2002); } \\
\text { Sureshchandar et al. (2002); Ekinci et al. (2008); Lien and } \\
\text { Kao (2008); Awan et al. (2011); Tan (2014); Yuen and Thai } \\
\text { (2015) }\end{array}$ \\
\hline Service quality and service convenience $\rightarrow$ customer satisfaction & Kaura (2013) \\
\hline Service quality and perceived value $\rightarrow$ customer satisfaction & Lai (2004); Hu et al. (2009); Adeola and Adebiyi (2014) \\
\hline Personality factors $\rightarrow$ customer satisfaction & $\begin{array}{l}\text { Gountas and Gountas (2007); Orth et al. (2010); Jani and Han } \\
\text { (2014) }\end{array}$ \\
\hline Brand personality and brand experience $\rightarrow$ customer satisfaction & Brakus et al. (2009) \\
\hline Employee satisfaction $\rightarrow$ customer satisfaction & Pugh et al. (1983); Jeon and Choi (2012) \\
\hline $\begin{array}{l}\text { Employee satisfaction, adaptive selling and dominance } \rightarrow \text { customer } \\
\text { satisfaction }\end{array}$ & Evanschitzky et al. (2012) \\
\hline Customer orientation of service employees $\rightarrow$ customer satisfaction & Hennig-Thurau (2004) \\
\hline Equity $\rightarrow$ customer satisfaction & Andreassen (2000); Naser (2002) \\
\hline Customer based brand equity $\rightarrow$ customer satisfaction & Nam et al. (2011) \\
\hline Customer expertise $\rightarrow$ customer satisfaction & Naser (2002) \\
\hline Customers' experience $\rightarrow$ customer satisfaction & Johnson and Fornell (1991) \\
\hline Marketing mix elements ( $7 \mathrm{Ps}) \rightarrow$ customer satisfaction & $\begin{array}{l}\text { Yelkur (2000); AmyPoh et al. (2012); Thusyanthy and } \\
\text { Senthilnathan (2012); Mucai et al. (2013) }\end{array}$ \\
\hline $\begin{array}{l}\text { Price, delivery performance, supplier know-how and personal } \\
\text { interaction } \rightarrow \text { customer satisfaction }\end{array}$ & Cater and Cater (2009) \\
\hline Organizational culture $\rightarrow$ customer satisfaction & Gillespie et al. 2008 \\
\hline
\end{tabular}

Although the preceding scientific studies address various antecedents of customer satisfaction, past studies also have investigated different outcomes of customer satisfaction. 


\subsection{Outcomes Associated with Customer Satisfaction}

Analysis of scientific literature suggests that customer satisfaction is an important driver of financial performance, profitability, shareholder value, return on investment, price sensitivity, customer loyalty, consumer based retailer equity, firm based brand equity, word-of-mouth, purchase intention, repeat-purchase intention and customer retention (e.g., Fornell, 1992; Hallowell, 1996; Anderson et al., 1997; Soderlund, 1998; Cronin, Brady, \& Hult, 2000; Rust et al., 2002; Matzler et al., 2005; Stock, 2005; Gustaffsson, Johnson, \& Roos, 2006; Pappu \& Quester, 2006; Walsh, Evanschitzky, \& Wunderlich, 2008; Torres \& Tribo, 2011; Tuu \& Olsen, 2012).

Rust et al. (2002) affirm that firms can achieve higher financial return along with its underlying focus on customer satisfaction. In other words, customer satisfaction has an impact on financial performance. Specifically, Hallowell (1996), Yeung and Ennew (2000), and Luo and Homburg (2007) suggest firm's profitability is a significant outcome of customer satisfaction. Matzler et al. (2005) remark that there is a positive relationship between customer satisfaction and shareholder value. Further, both customer satisfaction and productivity are positively related with return on investment for products and services (Anderson et al., 1997). Stock (2005) highlights that inverse relationship between customer satisfaction and price sensitivity (i.e., when the customers are satisfied with the products or services and they are less sensitive for the price).

Empirical studies demonstrate that customer satisfaction produces a stronger customer loyalty (Fornell, 1992; Rust \& Zahorik, 1993; Jones \& Sasser, 1995; Back \& Parks, 2003; Yoon \& Uysal, 2005). Indeed, Brunner, Stocklin, and Opwis (2008) suggest that both customer satisfaction and image have impact on customer loyalty. Moreover, according to associative network memory model is applied from cognitive psychology, there is a positive relationship exist between customer satisfaction and consumer based retailer equity, where consumer based retailer equity consist of four dimensions namely, retailer awareness, retailer associations, retailer perceived quality, and retailer loyalty (Pappu \& Quester, 2006). In addition, Torres and Tribo (2011) remark that direct positive effect move from customer satisfaction to firm based brand equity. On the other hand, Nam et al. (2011) shows customer satisfaction mediates the relationship between customer based brand equity and customer loyalty.

Soderlund (1998) argues that customer satisfaction produces positive word-of-mouth, whilst dissatisfied customers transmits negative word-of-mouth. On the other hand, previous marketing studies affirm customer satisfaction creates positive purchase intention towards products or services (Walsh et al., 2008; Tuu \& Olsen, 2012). According to Cronin et al. (2000) and Kuo, Hu, and Yang (2013), there is a positive association between customer satisfaction and repeat-purchase intention. Further, Kuo et al. (2013) also state that in the context of online shopping, word-of-mouth positively moderate the relationship between customer satisfaction and repeat-purchase intention. It is important to note that this customer satisfaction ultimately creates customer retention (Hansemark \& Albinsson, 2004; Gustaffsson et al., 2006).

As can be discussed in the above, the outcomes associated with customer satisfaction are presented in the Table 2.

Table 2. Outcomes of customer satisfaction

\begin{tabular}{ll}
\hline Outcomes of customer satisfaction & Source \\
\hline Customer satisfaction $\rightarrow$ financial performance & Rust et al. (2002) \\
Customer satisfaction $\rightarrow$ profitability & Hallowell (1996); Yeung and Ennew (2000); Luo and \\
& Homburg (2007) \\
Customer satisfaction $\rightarrow$ shareholder value & Matzler et al. (2005) \\
Customer satisfaction $\rightarrow$ return on investment & Anderson et al. (1997) \\
Customer satisfaction $\rightarrow$ price sensitivity & Stock (2005) \\
Customer satisfaction $\rightarrow$ customer loyalty & Fornell (1992); Rust and Zahorik (1993); Jones and Sasser \\
& (1995); Back and Parks (2003); Yoon and Uysal (2005); \\
Customer satisfaction $\rightarrow$ consumer based retailer equity & Brunner et al. (2008) \\
Customer satisfaction $\rightarrow$ firm based brand equity & Pappu and Quester (2006) \\
Customer satisfaction $\rightarrow$ word-of-mouth & Torres and Tribo (2011) \\
Customer satisfaction $\rightarrow$ purchase intention & Soderlund (1998) \\
Customer satisfaction $\rightarrow$ repeat-purchase intention & Walsh et al., (2008); Tuu and Olsen (2012) \\
Customer satisfaction $\rightarrow$ customer retention & Cronin et al. (2000); Kuo et al. (2013) \\
\hline
\end{tabular}




\section{Conclusion}

The preceding comprehensive review gives descriptions for various antecedent and outcome variables of customer satisfaction from past studies. Further, service quality, service convenience, perceived value, personality factors, brand personality, brand experience, employee satisfaction, adaptive selling, dominance, customer orientation of service employees, equity, customer based brand equity, customer expertise, customer's experience, marketing mix and extended marketing mix elements, delivery performance, supplier know-how, personal interaction and organizational culture are identified as antecedents of customer satisfaction. In addition, several variables are identified as outcomes of customer satisfaction, namely, financial performance, shareholder value, return on investment, price sensitivity, customer loyalty, consumer based retailer equity, firm based brand equity, word-of-mouth, purchase intention, repeat-purchase intention and customer retention.

To extend and facilitate further studies two comprehensive models are presented to show the antecedents and outcome variables of customer satisfaction with the literature support (see Figure 1 and Figure 2). Importantly, this study uses previous literatures in bank marketing, business and industrial marketing, business to business marketing, business research, consumer research, economic psychology, hospitality management, information systems, Islamic marketing, management, marketing, professional service marketing, quality and service sciences, retailing, service industry, service industry management, services marketing, service quality, social and humanistic sciences, strategic marketing, tourism management, tourism research, travel and tourism marketing, and work and organizational psychology (e.g., Pugh et al., 1983; Johnson \& Fornell, 1991; Oliver, 1993; Rust \& Zahorik, 1993; Hallowell, 1996; Soderlund, 1998; Andreassen, 2000; Dabholkar et al., 2000; Yelkur, 2000; Yeung \& Ennew, 2000; Heung et al., 2002; Naser, 2002; Rust et al., 2002; Sureshchandar et al., 2002; Back \& Parks, 2003; Hansemark \& Albinsson, 2004; Hennig-Thurau, 2004; Lai, 2004; Stock, 2005; Yoon \& Uysal, 2005; Gustaffsson et al., 2006; Gountas \& Gountas, 2007; Luo \& Homburg, 2007; Ekinci et al., 2008; Gillespie et al., 2008; Walsh et al., 2008; Brakus et al., 2009; Cater \& Cater, 2009; Hu et al., 2009; Cronin et al., 2000; Orth et al., 2010; Awan et al., 2011; Nam at al., 2011; Torres \& Tribo, 2011; AmyPoh et al., 2012; Evanschitzky et al., 2012; Jeon \& Choi, 2012; Kaura, 2013; Mucai et al., 2013; Adeola \& Adebiyi, 2014; Yuen \& Thai, 2015) to review the antecedent and outcome variables associate with customer satisfaction and to formulate comprehensive models. Therefore, this study will assist the customer satisfaction related future studies. In fact, this study can be further extended by considering other relevant antecedent and outcome variables to customer satisfaction, excluding the constructs and dimensions, which are considered for this study. Moreover, in the electronic context, customer satisfaction is considered as a critical factor (Anderson \& Srinivasan, 2003; Ankit, 2011), and thus, the future studies can be extended by incorporate the antecedent and outcome variables for electronic customer satisfaction. 


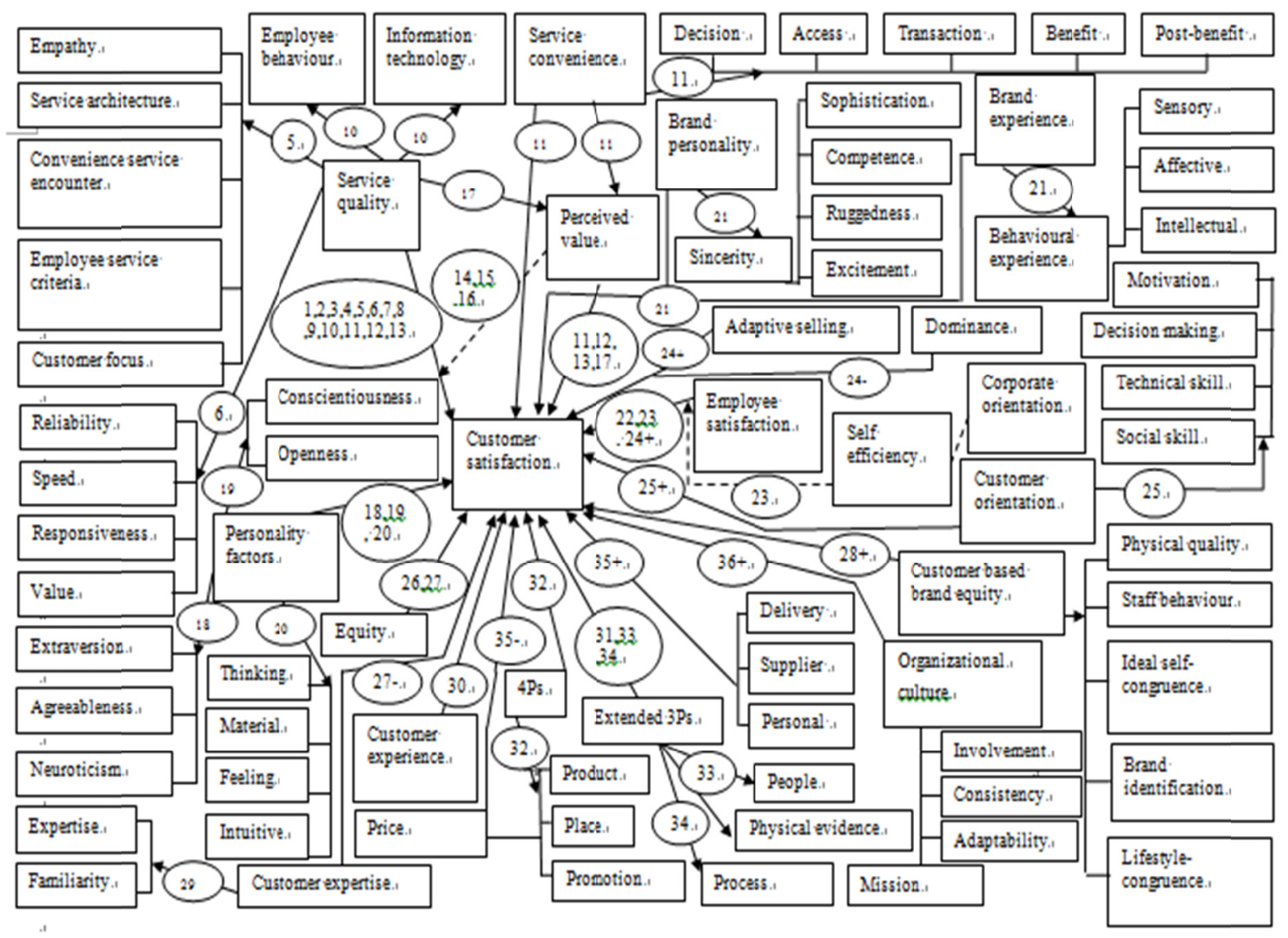

Figure 1. A comprehensive model on the antecedents of customer satisfaction

In Figure 1, the numbers (and signs) in a circle indicate respective references as indicated below.

\begin{tabular}{|c|c|c|c|}
\hline SN & Reference & SN & Reference \\
\hline 1. & Oliver (1993) & 19. & Jani \& Han (2014) \\
\hline 2. & Dabholkar et al. (2000) & 20. & Gountas \& Gountas (2007) \\
\hline 3. & Heung et al. (2002) & 21. & Brakus et al. (2009) \\
\hline 4. & Sureshchandar et al. (2002) & 22. & Pugh et al. (1983) \\
\hline 5. & Awan et al. (2011) & 23. & Jeon \& Choi (2012) \\
\hline 6. & Yuen \& Thai (2015) & 24. & Evanschitzky et al. (2012) \\
\hline 7. & Ekinci et al. (2008) & 25. & Hennig-Thurau (2004) \\
\hline 8. & Lien \& Kao (2008) & 26. & Andreassen (2000) \\
\hline 9. & $\operatorname{Tan}(2014)$ & 27. & Naser (2002) \\
\hline 10. & Kaura (2013) & 28. & Nam et al. (2011) \\
\hline 11. & Lai (2004) & 29. & Alba \& Hutchinson (1987) \\
\hline 12. & Hu et al. (2009) & 30. & Johnson \& Fornell (1991) \\
\hline 13. & Adeola \& Adebiyi (2014) & 31. & Yelkur (2000) \\
\hline 14. & Ismail et al. (2009a) & 32. & AmyPoh et al. (2012) \\
\hline 15. & Ismail et al. (2009b) & 33. & Thusyanthy \& Senthilnathan (2012) \\
\hline 16. & Raza et al. (2012) & 34. & Mucai et al. (2013) \\
\hline 17. & Malik (2012) & 35. & Cater \& Cater (2009) \\
\hline 18. & Orth et al. (2010) & 36. & Gillespie et al. (2008) \\
\hline
\end{tabular}




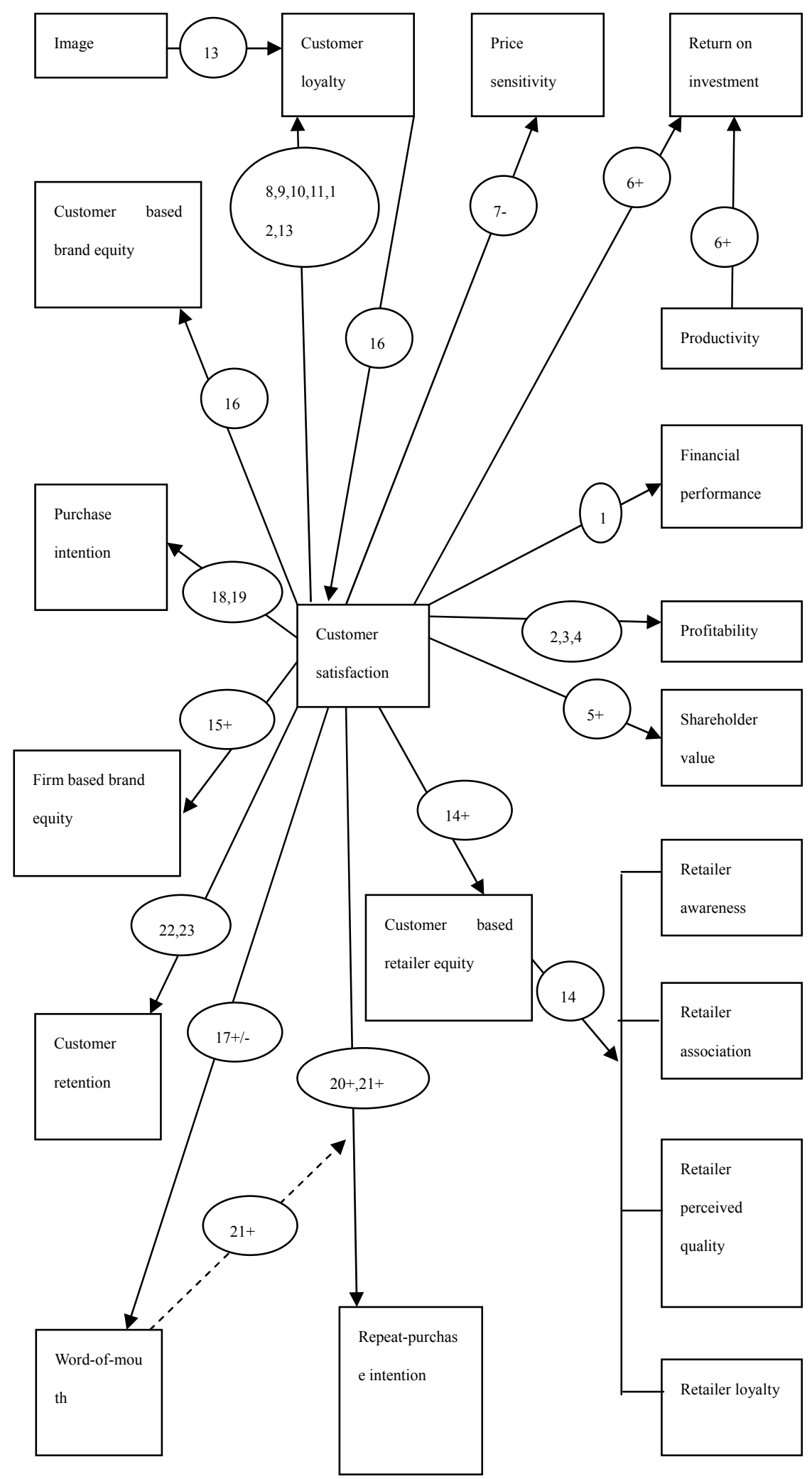

Figure 2. A comprehensive model on the outcomes of customer satisfaction

In Figure 2, the numbers (and signs) in a circle indicate respective references as indicated below. 


\begin{tabular}{llll}
\hline SN & Reference & SN & Reference \\
\hline 1. & Rust et al. (2002) & 13. & Brunner et al. (2008) \\
2. & Hallowell (1996) & 14. & Pappu \& Quester (2006) \\
3. & Yeung \& Ennew (2000) & 15. & Torres \& Tribo (2011) \\
4. & Luo \& Homburg (2007) & 16. & Nam et al. (2011) \\
5. & Matzler et al. (2005) & 17. & Soderlund (1998) \\
6. & Anderson et al. (1997) & 18. & Walsh et al. (2008) \\
7. & Stock (2005) & 19. & Tuu \& Olsen (2012) \\
8. & Fornell (1992) & 20. & Cronin et al. (2000) \\
9. & Rust \& Zahorik (1993) & 21. & Kuo et al. (2013) \\
10. & Jones \& Sasser (1995) & 22. & Hansemark \& Albinsson (2004) \\
11. & Back \& Parks (2003) & 23. & Gustaffsson et al. (2006) \\
12. & Yoon \& Uysal (2005) & & \\
\hline
\end{tabular}

\section{References}

Adams, J. S., \& Freedman, S. (1976). Equity theory revisited: Toward a general theory of social interaction. Advances in Experimental Social Psychology, 9, 421-436.

Adams, S. J. (1965). Inequity in social exchange. In L. Berkowitz (Ed.), Advances in Experimental Social Psychology (pp. 267-299). New York: Academic Press.

Adeola, M. M., \& Adebiyi, S. O. (2014). Service quality, perceived value and customer satisfaction as determinant of airline choice in Nigeria. International Letters of Social and Humanistic Sciences, 20, 66-80. http://dx.doi.org/10.18052/www.scipress.com/ILSHS.20.66

Alba, J. W., \& Hutchinson, J. W. (1987). Dimensions of consumer expertise. Journal of Consumer Research, 13(4), 411-454.

Al-Hawari, M., \& Ward, T. (2006). The effect of automated service quality on Australian banks' financial performance and the mediating role of customer satisfaction. Marketing Intelligence and Planning, 24(2), 127-147. http://dx.doi.org/10.1108/02634500610653991

AmyPoh, A. L., Saludin, M. N., \& Mukaidono, M. (2012). Deriving consensus rankings via multicriteria decision making methodology. Journal of Wireless Mobile Networks, Ubiquitous Computing, and Dependable Applications, 3(3), 94-112. http://dx.doi.org/10.1108/17515631211194571

Anderson, E. W., Fornell, C., \& Lehmann, D. R. (1994). Customer satisfaction, market share, and profitability: findings from Sweden. Journal of Marketing, 58(3), 53-66. http://dx.doi.org/10.2307/1252310

Anderson, E. W., Fornell, C., \& Mazvancheryl, S. K. (2004). Customer satisfaction and shareholder value. Journal of Marketing, 68(4), 172-185. http://dx.doi.org/10.1509/jmkg.68.4.172.42723

Anderson, E. W., Fornell, C., \& Rust, R. T. (1997). Customer satisfaction, productivity, and profitability: differences between goods and services. Marketing Scienc, 16(2), 129-145. http://dx.doi.org/10.1287/mksc.16.2.129

Anderson, R. E., \& Srinivasan, S. S. (2003). E-satisfaction and e-loyalty: a contingency framework. Psychology and Marketing, 20(2), 123-138. http://dx.doi.org/10.1002/mar.10063

Andreassen, T. W. (2000). Antecedents to satisfaction with service recovery. European Journal of Marketing, 34(1/2), 156-175. http://dx.doi.org/10.1108/03090560010306269

Ankit, S. (2011). Factors influencing online banking customer satisfaction and their importance in improving overall retention levels: an Indian banking perspective. Information and Knowledge Management, 1(1), 45-54.

Awan, H. M., Bukhari, K. S., \& Iqbal, A. (2011). Service quality and customer satisfaction in the banking sector: a comparative study of conventional and Islamic banks in Pakistan. Journal of Islamic Marketing, 2(3), 203-224. http://dx.doi.org/10.1108/17590831111164750

Back, K. J., \& Parks, S. C. (2003). A brand loyalty model involving cognitive, affective, and conative brand loyalty and customer satisfaction. Journal of Hospitality and Tourism Research, 27(4), 419-435. http://dx.doi.org/10.1177/10963480030274003 
Bearden, W. O., \& Teel, J. E. (1983). Selected determinants of consumer satisfaction and complaint reports. Journal of Marketing Research, 20(1), 21-28. http://dx.doi.org/10.2307/3151408

Blau, P. M. (1960). A theory of social integration. American Journal of Sociology, 65(6), 545-556.

Brady, M. K., \& Robertson, C. J. (2001). Searching for a consensus on the antecedent role of service quality and satisfaction: an exploratory cross-national study. Journal of Business Research, 51(1), 53-60. http://dx.doi.org/10.1016/S0148-2963(99)00041-7

Brakus, J. J., Schmitt, B. H., \& Zarantonello, L. (2009). Brand experience: what is it? how is it measured? does it affect loyalty? Journal of Marketing, 73(3), 52-68. http://dx.doi.org/10.1509/jmkg.73.3.52

Brunner, T. A., Stocklin, M., \& Opwis, K. (2008). Satisfaction, image and loyalty: new versus experienced $\begin{array}{llll}\text { customers. } & \text { European Journal of }\end{array}$ http://dx.doi.org/10.1108/03090560810891163

Cater, B., \& Cater, T. (2009). Relationship-value - based antecedents of customer satisfaction and loyalty in manufacturingRelationship-value - based antecedents of customer satisfaction and loyalty in manufacturing. Journal of Business and Industrial Marketing, 24(8), 585-597. http://dx.doi.org/10.1108/08858620910999457

Churchill, G., \& Suprenant, C. (1982). An investigation into the determinants of customer satisfaction. Journal of Marketing Research, 19(4), 491-504. http://dx.doi.org/10.2307/3151722

Cronin, J. J., Brady, M. K., \& Hult, G. T. M. (2000). Assessing the effects of quality, value, and customer satisfaction on consumer behavioral intentions in service environments. Journal of Retailing, 76(2), 193-218. http://dx.doi.org/10.1016/S0022-4359(00)00028-2

Dabholkar, P. A., Shepherd, C. D., \& Thorpe, D. I. (2000). A comprehensive framework for service quality: an investigation of critical conceptual and measurement issues through a longitudinal study. Journal of Retailing, 76(2), 139-173. http://dx.doi.org/10.1016/S0022-4359(00)00029-4

Ekinci, Y., Dawes, P. L., \& Massey, G. R. (2008). An extended model of the antecedents and consequences of consumer satisfaction for hospitality services. European Journal of Marketing, 42(1), 35-68. http://dx.doi.org/10.1108/03090560810840907

Estiri , M., Hosseini, F., Yazdani, H., \& Nejad, H. J. (2011). Determinants of customer satisfaction in Islamic banking: evidence from Iran. International Journal of Islamic and Middle Eastern Finance and Management, 4(4), 295-307. http://dx.doi.org/10.1108/17538391111186546

Evanschitzky, H., Sharma, A., \& Prykop, C. (2002). The role of the sales employee in securing customer $\begin{array}{llll}\text { satisfaction. European Journal of } & \text { 489-508. }\end{array}$ http://dx.doi.org/10.1108/03090561211202576

Fornell, C. A. (1992). National customer satisfaction barometer: the Swedish experience. Journal of Marketing, 56(1), 6-21. http://dx.doi.org/10.2307/1252129

Fornell, C., Johnson, M. D., Anderson, E. W., Cha, J., \& Bryant, B. E. (1996). The American customer satisfaction index: nature, purpose and findings. Journal of Marketing, 60(4), 7-18.

Fornell, C., Mithas, S., Morgeson, F. V., \& Krishnan, M. S. (2006). Customer satisfaction and stock prices: high returns, low risk. Journal of Marketing, 70(1), 3-14. http://dx.doi.org/10.1509/jmkg.2006.70.1.3

Getty, J. M., \& Thompson, K. N. (1994). The relationship between quality, satisfaction and recommending behaviour in lodging decision. Journal of Hospitality and Leisure Marketing, 2(3). http://dx.doi.org/10.1300/J150v02n03_02

Giese, J. L., \& Cote, J. A. (2000). Defining consumer satisfaction. Academy of Marketing Science Review, 2000(1), $1-24$.

Gillespie, M. A., Denison, D. R., Haaland, S., Smerek, R., \& Neale, W. S. (2008). Linking organizational culture and customer satisfaction: results from two companies in different industries. European journal of work and Organizational psychology, 17(1), 112-132. http://dx.doi.org/10.1080/13594320701560820

Gountas, J., \& Gountas, S. (2007). Personality orientations, emotional states, customer satisfaction, and intention to repurchase. Journal of Business Research, 60(1), 72-75. http://dx.doi.org/10.1016/j.jbusres.2006.08.007 
Gustaffsson, A., Johnson, M. J., \& Roos, I. (2006). The effects of customer satisfaction, relationship commitment dimensions, and triggers on customer retention. Journal of Marketing, 69(4), 210-218. http://dx.doi.org/10.1509/jmkg.2005.69.4.210

Hallowell, R. (1996). The relationships of customer satisfaction, customer loyalty, and profitability: an empirical study. International Journal of Service Industry Management, 7(4), 27-42. http://dx.doi.org/10.1108/09564239610129931

Halstead, D., Hartman, D., \& Schmidt, S. L. (1994). Multisource effects on the satisfaction formation process. Journal of the Academy of Marketing Science, 22(2), 114-129. http://dx.doi.org/10.1177/0092070394222002

Hansemark, O. C., \& Albinsson, M. (2004). Customer satisfaction and retention: the experiences of individual employees. Managing Service Quality: An International Journal, 14(1), 40-57. http://dx.doi.org/10.1108/09604520410513668

Hennig-Thurau, T. (2004). Customer orientation of service employees: its impact on customer satisfaction, commitment, and retention. International Journal of Service Industry Management, 15(5), 460-478. http://dx.doi.org/10.1108/09564230410564939

Heung, C. S., Wong, M. Y., \& Qu, H. (2002). A study of tourists' satisfaction and post-experience behavioral intentions in relation to airport restaurant services in the Hong Kong SAR. Journal of Travel and Tourism Marketing, 12(2/3), 111-135. http://dx.doi.org/10.1300/J073v12n02_07

Howard, J. D., \& Sheth, J. N. (1969). The Theory of Buyer Behavior. New York: John Wiley \& Sons.

$\mathrm{Hu}, \mathrm{H} .$, Kandampully, J., \& Juwaheer, T. D. (2009). Relationships and impacts of service quality, perceived value, customer satisfaction, and image: an empirical study. The Service Industries Journal, 29(2), 111-125. http://dx.doi.org/10.1080/02642060802292932

Huseman, R. C., Hatfield, J. D., \& Miles, E. W. (1987). A new perspective on equity theory: the equity sensitivity

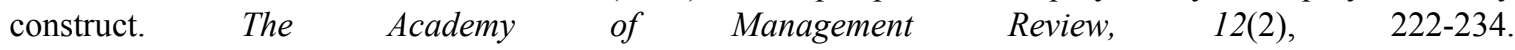
http://dx.doi.org/10.5465/AMR.1987.4307799

Islam, T., Kassim, N. A., Ali, G., \& Sadiq, M. (2014). Organizational learning culture and customer satisfaction: the mediating role of normative commitment. The Learning Organization, 21(6), 392-404. http://dx.doi.org/10.1108/TLO-07-2014-0040

Ismail, A., Abdullah, M. M. B., \& Francis, S. K. (2009a). Exploring the relationships among service quality features, perceived value and customer satisfaction. Journal of Industrial Engineering and Management, 2(1), 230-250. http://dx.doi.org/10.3926/jiem..v2n1.p230-250

Ismail, A., Alli, N., \& Abdullah, M. M. (2009b). Perceive value as a moderator on the relationship between service quality features and customer satisfaction. International Journal of Business and Management, 4(2), 71-79. http://dx.doi.org/10.5539/ijbm.v4n2p71

Jani, D., \& Han, H. (2014). Personality, satisfaction, image, ambience, and loyalty: testing their relationships in the hotel industry. International Journal of Hospitality Management, 37, 11-20. http://dx.doi.org/10.1016/j.ijhm.2013.10.007

Jeon, H., \& Choi, B. (2012). The relationship between employee satisfaction and customer satisfaction. Journal of Services Marketing, 26(5), 332-341. http://dx.doi.org/10.1108/08876041211245236

Johnson, M. D., \& Fornell, C. (1991). A framework for comparing customer satisfaction across individuals and product categories. Journal of Economic Psychology, 12(2), 267-286. http://dx.doi.org/10.1016/0167-4870(91)90016-M

Jones, T., \& Sasser, W. (1995). Why satisfied customers defect. Harvard Business Review, 73(6), 88-99.

Karunakaran, A. S. J., \& Thusyanthy,V. (2016). A review on the relationship variables to customer satisfaction. Global Journal of Management and Business Research: E Marketing, 16(5), 87-91.

Kaura, V. (2013). Antecedents of customer satisfaction: a study of Indian public and private sector banks. International Journal of Bank Marketing, 31(3), 167-186. http://dx.doi.org/10.1108/02652321311315285

Keith, R. J. (1960). The marketing revolution. Journal of Marketing, 24(3), 35-38. http://dx.doi.org/10.2307/1248704 
Kuo, Y., Hu, T., \& Yang, S. (2013). Effects of inertia and satisfaction in female online shoppers on repeat-purchase intention. Managing Service Quality: An International Journal, 23(3), 168-187. http://dx.doi.org/10.1108/09604521311312219

Lai, T. L. (2004). Service quality and perceived value's impact on satisfaction, intention and usage of short message service (SMS). Information Systems Frontiers, 6(4), 353-368. http://dx.doi.org/10.1023/B:ISFI.0000046377.32617.3d

Lien, N., \& Kao, S. (2008). The effects of service quality dimensions on customer satisfaction across different service types: alternative differentiation as a moderator. Advances in Consumer Research, 35, 522-526.

Lin, C., Wu, H., \& Chang, Y. (2011). The critical factors impact on online customer satisfaction. Procedia Computer Science, 3, 276-281. http://dx.doi.org/10.1016/j.procs.2010.12.047

Luo, X., \& Homburg, C. (2007). Neglected outcomes of customer satisfaction. Journal of Marketing, 71(2), 133-149.

Malik, S. U. (2012). Customer Satisfaction, perceived service quality and mediating role of perceived value. International Journal of Marketing Studies, 4(1), 68- 76. http://dx.doi.org/10.5539/ijms.v4n1p68

Matzler, K., Hinterhuber, H. H., Daxer, C., \& Huber, M. (2005). The relationship between customer satisfaction and shareholder value. Total Quality Management and Business Excellence, 16(5), 671-680. http://dx.doi.org/10.1080/14783360500077674

Mucai, G. P., Mbaeh, E. K., \& Noor, A. I. (2013). Extended marketing mix and customer's satisfaction in classified non-star hotels in Meru Municipality Kenya. International Review of Management and Business Research, 2(3), 691-696.

Nam, J., Ekinci, Y., \& Whyatt, G. (2011). Brand equity, brand loyalty and consumer satisfaction. Annals of Tourism Research, 38(3), 1009-1030. http://dx.doi.org/10.1016/j.annals.2011.01.015

Naser, A. J. K. (2002). Customer satisfaction and retail banking: an assessment of some of the key antecedents of customer satisfaction in retail banking. International Journal of Bank Marketing, 20(4), 146-160. http://dx.doi.org/10.1108/02652320210432936

Nilssona, L., Johnsonb, M. D., \& Gustafsson, A. (2001). The impact of quality practices on customer satisfaction and business results: product versus service organizations. Journal of Quality Management, 6, 5-27. http://dx.doi.org/10.1016/S1084-8568(01)00026-8

Oliver, R. L. (1993). Cognitive, affective and attribute bases of the satisfaction response. Journal of Consumer Research, 20(3), 418-430. http://dx.doi.org/10.1086/209358

Oliver, R. L. (1997). Satisfaction: A Behavioral Perspective on the Consumer. New York: The McGraw-Hill Companies Inc.

Oliver, R. L. (1999). Whence consumer loyalty? Journal of Marketing, 63(4), 33-44. http://dx.doi.org/10.2307/1252099

Oliver, R. L., \& Swan, J. E. (1989). Consumer perceptions of interpersonal equity and satisfaction in transactions: a field survey approach. Journal of Marketing, 53(2), 21-35. http://dx.doi.org/10.2307/1251411

Orth, U. R., Limon, Y., \& Rose, G. (2010). Store-evoked affect, personalities, and consumer emotional attachment to brands. Journal of Business Research, 63(11), 1202-1208. http://dx.doi.org/10.1016/j.jbusres.2009.10.018

Padma, P., Rajendran, C., \& Lokachari, P. S. (2010). Service quality and its impact on customer satisfaction in Indian hospitals: perspectives of patients and their attendants. Benchmarking: An International Journal, 17(6), 807-841.

Pappu, R., \& Quester, P. (2006). Does customer satisfaction lead to improved brand equity? an empirical examination of two categories of retail brands. Journal of Product and Brand Management, 15(1), 4-14. http://dx.doi.org/10.1108/10610420610650837

Pugh, S. D., Dietz, J., Wiley, J. W., \& Brooks, S. M. (2002). Driving service effectiveness through employee-customer linkages. The Academy of Management Executive, 16(4), 73-84. http://dx.doi.org/10.5465/AME.2002.8951330

Rossomme, J. (2003). Customer satisfaction measurement in a business-to-business context: a conceptual framework. Journal of Business and Industrial Marketing, 18(2), 179-195. http://dx.doi.org/10.1108/08858620310463097 
Rukshani, K., \& Senthilnathan, S. (2013). A review on the relationship variables to employee morale and organizational trust. International Journal of Innovative Research and Practices, 1(10), 8-15.

Rust, R. T., \& Oliver, R. L. (1994). Service quality: insights and managerial implication from the frontier. In R. T. Rust \& R. L. Oliver (Eds.), Service Quality: New Directions in Theory and Practice (pp. 1-19). Thousand Oaks, CA: Sage Publications.

Rust, R. T., \& Zahorik, A. J. (1993). Customer satisfaction, customer retention, and market share. Journal of Retailing, 69(2), 193-215. http://dx.doi.org/10.1016/0022-4359(93)90003-2

Rust, R. T., Moorman, C., \& Dickson, P. R. (2002). Getting return on quality: revenue expansion, cost reduction, or both? Journal of Marketing, 65(4), 7-24.

Santouridis, I., \& Trivellas, P. (2010). Investigating the impact of service quality and customer satisfaction on customer loyalty in mobile telephony in Greece. The TQM Journal, 22(3), 330-343. http://dx.doi.org/10.1108/17542731011035550

Sarker, M. A. H., Aimin, W., \& Begum, S. (2012). Investigating the impact of marketing mix elements on tourists 'satisfaction: an empirical study on East Lake. European Journal of Business and Management, 4(7), 273-282.

Soderlund, M. (1998). Customer satisfaction and its consequences on customer behaviour revisited. International Journal of Service Industry Management, 9(2), 169-188. http://dx.doi.org/10.1108/09564239810210532

Stock, R. M. (2005). Can customer satisfaction decrease price sensitivity in business-to-business markets? Journal of Business-to-Business Marketing, 12(3), 59-87. http://dx.doi.org/10.1300/J033v12n03_03

Sureshchandar, G. S., Rajendran, C., \& Anantharaman, R. N. (2002). The relationship between service quality and customer satisfaction: a factor specific approach. Journal of Services Marketing, 16(4), 363-379. http://dx.doi.org/10.1108/08876040210433248

Tan, T. A. G. (2014). Integrating justice theory and service quality concept to evaluate customer recovery satisfaction. IAMURE International Journal of Business and Management, 8(1).

Thusyanthy, V. (2014). A review on the relationship variables to job design. International Journal of Business Research and Management (IJBRM), 5(5), 81-87.

Thusyanthy, V., \& Senthilnathan, S. (2012). Customer satisfaction in terms of physical evidence and employee interaction. IUP Journal of Marketing Management, 11(3), 7-24.

Thusyanthy, V., \& Tharanikaran, V. (2015). The relationship variables to celebrity endorsement and brand equity: a comprehensive review. International Journal of Business and Management, 10(11), 212-221. http://dx.doi.org/10.5539/ijbm.v10n11p212

Torres, A., \& Tribo, J. A. (2011). Customer satisfaction and brand equity. Journal of Business Research, 64(10), 1089-1096. http://dx.doi.org/10.1016/j.jbusres.2010.12.001

Tse, D. K., \& Wilton, P. C. (1988). Models of consumer satisfaction formation: an extension. Journal of Marketing Research, 25(2), 204-212. http://dx.doi.org/10.2307/3172652

Tuu, H. H., \& Olsen, S. O. (2012). Certainty, risk and knowledge in the satisfaction-purchase intention relationship in a new product experimen. Asia Pacific Journal of Marketing and Logistics, 24(1), 78-101. http://dx.doi.org/10.1108/13555851211192713

Walsh, G., Evanschitzky, H., \& Wunderlich, M. (2008). Identification and analysis of moderator variables: investigating the customer satisfaction-loyalty link. European Journal of Marketing, 42(9/10), 977-1004. http://dx.doi.org/10.1108/03090560810891109

White, C. (2015). The impact of motivation on customer satisfaction formation: a self-determination perspective. European Journal of Marketing, 49(11/12), 1923-1940. http://dx.doi.org/10.1108/EJM-08-2014-0501

Yelkur, R. (2000). Customer satisfaction and the services marketing mix. Journal of Professional Service Marketing, 21(1), 105-115. http://dx.doi.org/10.1300/J090v21n01_07

Yeung, M. C. H., \& Ennew, C. T. (2000). From customer satisfaction to profitability. Journal of Strategic Marketing, 8(4), 313-326. http://dx.doi.org/10.1080/09652540010003663

Yoon, Y., \& Uysal, M. (2005). An examination of the effects of motivation and satisfaction on destination loyalty: a structural model. Tourism Management, 26(1), 45-56. http://dx.doi.org/10.1016/j.tourman.2003.08.016 
Yuen, K. F., \& Thai, V. (2015). Service quality and customer satisfaction in liner shipping. International Journal of Quality and Service Sciences, 7(2/3), 170-183. http://dx.doi.org/10.1108/IJQSS-02-2015-0024

\section{Copyrights}

Copyright for this article is retained by the author(s), with first publication rights granted to the journal.

This is an open-access article distributed under the terms and conditions of the Creative Commons Attribution license (http://creativecommons.org/licenses/by/4.0/). 